\title{
ポーラログラフを応用した耐蝕試験”
}

\author{
岡野一良**大田 行徳**北村義治** 山下㨁 ${ }^{* * *}$
}

\section{Corrosion Testing by the Polarographic Method}

Kazuyoshi Okano, Yukinori Ota, Yoshiharu Kitamura, and Sunao Yamashita

Applying the polarographic method to corrosion testing based on valtage-ampere curves, we have rapidly obtained comparatively accurate results, and especially have succeeded in the comparative testing for the solutions which were slight corrosive.

By this method we compared corrosion resisting properties of stainless steel and mild steel in sodium glutaminate solution.

\section{1. 緒管}

金属材料の耐蝕性を判定するためにわれわれは主とし て腐蝕による重量減から腐蝕度を决め，またその状態の 顕微鏡観察を行っている。

浴電圧一電流曲線により耐蝕性を判定する方法は, R. G. Y. 耐蝕試験法 ${ }^{1)}$ として山本洋一教授により提唱され たものであり，本年 3 月及び 5 月の 腐蝕防止第 97 委員 会月例会議に执いてその応用例等について同数授より詳 細な発表があった。われわれは R.G.Y. 耐蝕試験の精 度向上と迅速化をはかるためポーラログラフを応用して
浴電圧一電流曲線を連続的に自動記録し，グルタミン酸 ソー夕溶液に対する 3 種類のステンレス銅およひ胡唡の 耐蝕性の比較を試みた。

\section{2. 実 験 方 法}

(1) 試 片

a) 化学組成（第 1 表）

b) 形状扎よび寸法, $30 \mathrm{~mm} \times 30 \mathrm{~mm} \times 2 \mathrm{~mm}$ 板汱

c）表面仕上状態, JIS R 6001 粒度 400 番仕上

d）試娩前における試料の洗涤方式，石畧で水洗谣ア ルコール，エーテルの順序に洗滌して乾燥。

籍 1 表試料の化学組成

\begin{tabular}{|c|c|c|c|c|c|c|c|c|c|c|c|}
\hline 程 & 類 & 祀晃 & $\mathrm{C}$ & $\mathrm{Cr}$ & $\mathrm{N}_{1}$ & Mo & $\mathrm{Cu}$ & $\mathrm{S}_{1}$ & $\mathrm{Mn}$ & $P$ & $\mathrm{~S}$ \\
\hline 軟 & 糊 & 富 $\frac{上}{\mathrm{~F}}$ 鐡 & $0.18 \sim 0.2$ & - & - & - & - & $<0.35$ & $<0.7 \bar{\Sigma}$ & $<0 \mathrm{C} 4$ & $<3.01$ \\
\hline ステン & レス䑶话 & $\underset{\text { SUS }}{\text { JIS }}$ & C. 67 & 18.57 & 8.92 & - & - & 0.61 & 0.97 & $<0.04$ & $<0.03$ \\
\hline " & & $\begin{array}{l}\text { JIS } \\
\text { SUS } 13\end{array}$ & 0.025 & $17 . \mathrm{Co}$ & 14.20 & 2.04 & - & 0.58 & 2.12 & $<0.04$ & $<0.03$ \\
\hline " & & $\begin{array}{l}\text { INCO } \\
\text { NIONEL }\end{array}$ & 0.05 & $\therefore$ & 40 & 3.0 & 1.75 & $0.4 \mathrm{C}$ & 0.60 & - & - \\
\hline
\end{tabular}

\section{（2）実験装置}

第1図は電子管式ミリホルト記録計を用いたペン書き のポーラログラフ（横河電機製）を応用した耐蝕試娩装 置である。

この場合ポーラロクラフの水銀滴下電極および電解セ ルを取外し，そのかわりに巾 $150 \mathrm{~mm}$ 奥行 $100 \mathrm{~mm}$ 深さ $80 \mathrm{~mm}$ の硬質塩化ビニール製の测定槽を置きここの槽内 に腐蝕環境となるグルタミン酸ソータ溶泣 $750 \mathrm{cc}$ を人 れ，同一の材質形状および大ささの試片 2 枚を陽極およ

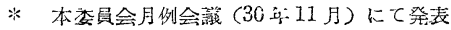

**味の素株式全仕川㥓工場

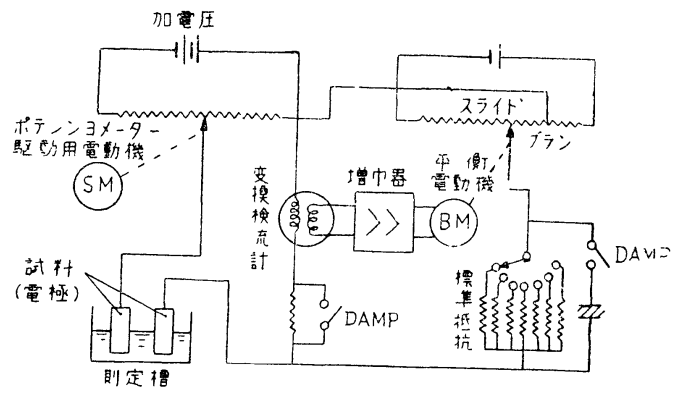

第1図 ポーラログラフを応用した耐蝕試験装置 


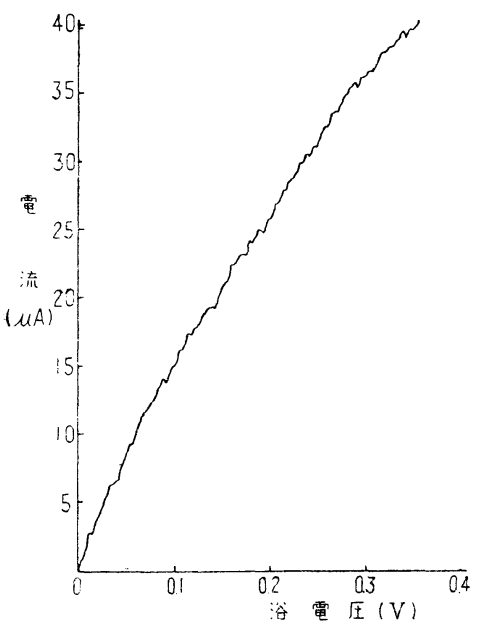

第 2 図 軟鍓の浴電压一電流曲線

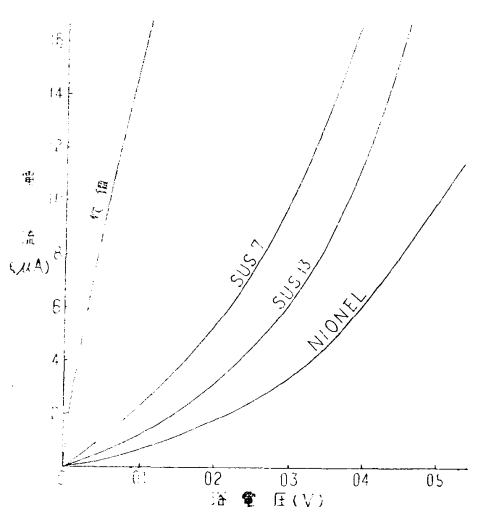

管 3 図 谷試料の浴電圧一電流曲線

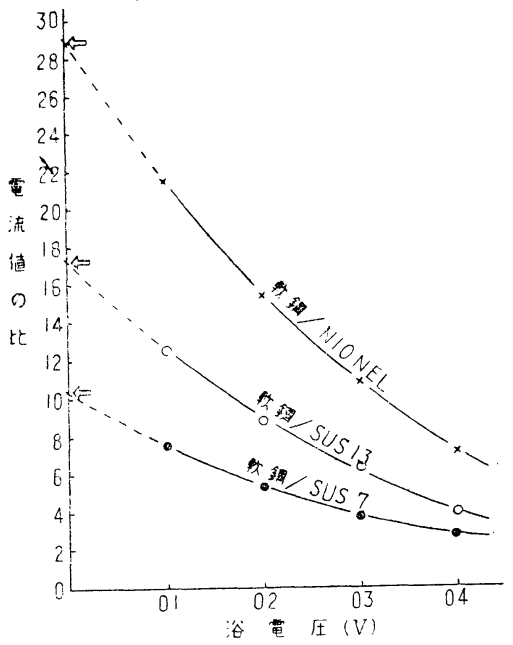

第4図軟銅に対する 3 種類のステンレス 鋼の電流值の比
び除極とし，両 極の漫漬面積を 試片の全表面積 0) $1 / 2$ すなわち $10.5 \mathrm{~cm}^{2}$ として 両極間の巨離孛 $55 \mathrm{~mm}$ に定め, 平面を问い合せ て琶啹に浸漬し た。笑験は各回 溶液を取換光， また同一試片の データーをとり なおす場合は試 片の表面を再研 磨して用いた。

（3）腐触環境 の性啠及び 状態

グルタミン酸 ソーダ溶液, $\mathrm{pH}$

7, Be 25.3 , 液湿 $15^{\circ} \mathrm{C}$

\section{3. 実験結果}

第1図に示し た実験装置でた とえば軟鋼に浴 電压を加光ると， グルタミン酸ソ 一ダ溶液の分解 電压 (約 $2 \mathrm{~V}$ ) 以下で電流を生 じ第 2 図のよう な溶電圧一電流 曲線加自働的に えがかれる。同 様に他の試料に ついてこの曲線 学求め比皎のた めに各曲線を重 ね合せたのが第 3 図である。そ して一定浴電圧 のもとにおいて 生ずる電流の大 さいもの程, こ
すいといわれる。これを具体的な数字として比較するに は永井氏の「酸謒抑制剂の効果判定における電気依導扊 測定の応用》」の中でとられている方法によった。すな わち基準とした試料 (乾銅) と比較する試料(ステンレス 鋼)の各浴電圧における電流优の比をプロットし,第4図 を得る。次にこの曲線を延長して浴電圧 OVにおける雨 試料の電流优の比 (同図矢印) を求め, この值より軟鋼 に対して NIONEL は約 29 倍，SUS 13 は約 17 倍，ま たSUS 7 は約 10 倍の耐蝕性があると推定できる。

\section{4. 結富}

浴電圧一電流曲線による耐蝕試験にポーラログラフを 応用した場合

（1）電流値の非常に低いところが直接ペン㫪で浴電压 に対する曲線としてえられるので耐蝕性を比較する場合 精度のよい結果がえられる。

(2) 試験厅法が簡単であり，迅速に結果がえられるの で，金属材料の購入試驗等に適すると思われる。-..つ 汾電圧一電流曲線は約 5 分間で記録できる。

（3）本実験の場合のように淠蝕性の少ない溶液に対す る材料の比較試験に特に適している。

(4) ポーラログラフはその機能上，記録計の電流值， 加電压範囲および記録紙の速度を数種類に変えることが できるので，各試料の耐蝕性の比較に最も適当な作動簿 囲をそれぞれ選定することができる。

われわれは今後さらに各種の材料および腐蝕環境につ いてこの試験方法による实娩を行い，その再現性を確か

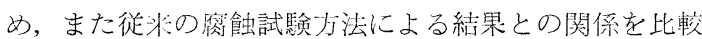
してみたい。

終りに本实鉷を在行うにあたり衔指導を賜わった工学博 士山本洋一教授に深く感謝の意を表する。

\section{参 考 文 献}

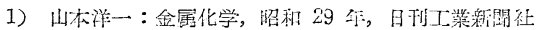

2) 永井一夫：防䖝技衔， 5，221，(1955)

(36頁より)

スクリーンの表面に附着する海中生物はスクリーンに 流入する直流電流により防止できる場合があるが，乙の 場合の所要条件は未確定である。

附記

本防蝕工事の施工に当って終始多大のご援助とご協力 を頂いた前載各会社の担当職員各位に対し深く謝意を表 する次第である。

\section{交献}

1.) Joseph B.Primer, Jr : Corrosion, 10, No.5 (1954)

2) J.H.Collins \& E.H.Thalman : Corrosion, 8, No.9 (1952

の溶液に対してイオン化する程度が大きく，腐蝕されや 